Article

\title{
Quantifying the Building Energy Dynamics of Manhattan, New York City, Using an Urban Building Energy Model and Localized Weather Data
}

\author{
Wenliang Li (D) \\ Department of Geography, Environment, and Sustainability, The University of North Carolina at Greensboro, \\ Greensboro, NC 27412,USA; w_li3@uncg.edu
}

Received: 12 May 2020; Accepted: 17 June 2020; Published: 23 June 2020

\begin{abstract}
Building sectors account for major energy use and greenhouse gas emissions in the US. While urban building energy-use modeling has been widely applied in many studies, limited studies have been conducted for Manhattan, New York City (NYC). Since the release of the new "80-by-50" law, the NYC government has committed to reducing carbon emissions by $80 \%$ by 2050 ; indeed, the government is facing a big challenge for reducing the energy use and carbon emissions. Therefore, understanding the building energy use of NYC with a high spatial and temporal resolution is essential for the government and local citizens in managing building energy use. This study quantified the building energy use of Manhattan in NYC with consideration of the local microclimate by integrating two popular modeling platforms, the Urban Weather Generator (UWG) and Urban Building Energy Modeling (UBEM). The research results suggest that (1) the largest building energy use is in central Manhattan, which is composed of large numbers of commercial buildings; (2) a similar seasonal electricity-use pattern and significantly different seasonal gas-use patterns could be found in Manhattan, NYC, due to the varied seasonal cooling and heating demand; and (3) the hourly energy-use profiles suggest only one electricity-use peak in the summer and two gas-use peaks in the winter.
\end{abstract}

Keywords: building energy use; localized weather data; urban building energy use model; Manhattan

\section{Introduction}

In the past decades, the world has experienced rapid economic development, population growth, and urban sprawl [1]. So far, over $55 \%$ of the world's population lives in cities, and it is predicted that 2.5 billion more people will be dwelling in cities by 2050 [2]. This rapid urbanization has brought several challenging issues, such as the significant increases in energy consumption and $\mathrm{CO}_{2}$ emissions [1]. Scholars project that urban energy consumption will be over 20,000 Mtoe (million tons of oil equivalent) by 2050 , which, in turn, would result in the shortage of energy and environmental degradation [3]. In response to these challenging issues, city governments throughout the whole world have proposed ambitious greenhouse gas emission reduction plans. For instance, the City of San Francisco and the City of London have set the emission reduction target at $40 \%$ and $60 \%$ by 2025 , respectively [4]. The City of Boston proposed a Greenovate Climate Action Plan and is targeting an emission reduction of $25 \%$ and $80 \%$ by 2020 and 2050, respectively [5]. No exception for the City of New York, where an $80 \%$ emission reduction by 2050 has been set as the goal [6]. Buildings, as the foundation and major component of a city, are contributing the majority of the energy consumption and greenhouse gas emissions within the city [3]. According to past studies, up to $75 \%$ of the energy consumption is contributed by urban buildings $[7,8]$, and over $50 \%$ of the electricity consumption is consumed by residential and commercial buildings in a city [3,9]. Therefore, understanding urban building energy dynamics is 
essential for managing urban energy consumption, reducing greenhouse gas emissions, improving energy-use efficiency, developing urban sustainable development plans, and optimizing urban system design [3,10-14].

Urban Building Energy Modeling (UBEM) has been proved effective in simulating and understanding urban building energy consumption $[15,16]$. With UBEM, city governments can manage the existing urban building energy consumption and investigate future potential energy savings through testing new techniques and building codes [17]. UBEM can be generally grouped into two branches: the top-down models and bottom-up models $[11,18]$. The top-down models analyze urban building energy consumption based on a group of buildings, and thus not able to analyze and explain the energy use of every single building $[19,20]$. Therefore, these models cannot provide a detailed energy-use analysis for a specific neighborhood. Moreover, most top-down models rely on historical data, which makes them difficult in testing the consequence of different energy retrofit strategies and technological advances. For instance, Hirst et al. [21] simulated the annual residential energy consumption of the US based on an econometric model. Zhang [22] examined the potential changes in regional energy use in China using the residents and corresponding energy consumption information, and also compared the results with other countries. Ozturk et al. [23] and Canyurt et al. [24] analyzed the relationship between energy use and demographic and economic factors using the genetic algorithms method in Turkey. While these studies have included major demographic, economic, and technological factors in energy-use modeling, new energy retrofit strategies and technological advances cannot be tested and verified as the models were only built based on past historical data on a large scale. In contrast, the bottom-up models focus on single buildings, where the energy use is thus analyzed for each building and, further, aggregated to the city, county, state, or national level. The bottom-up models are categorized into two types based on the modeling mechanisms: statistical models and physics-based models [25]. The statistical model simulates the energy use of single buildings based on the collected historical energy-use data and social-economic data. Hirst et al. [26] applied a regression model to analyze the impact of weather elements on household energy use based on utility data. Fung et al. [27] used a regression model to explore the impact of demographics, weather, and other equipment characteristics on residential energy use in Canada. Parti and Parti [28] used conditional demand analysis to analyze the relationship between household occupancy and electricity consumption in San Diego. Aydinalp et al. [29,30] proposed a national residential energy-use model based on neural networks. However, access to historical energy use and economic data may not be available for all cities. In contrast, the physics-based models estimate building energy use based on the physical characteristics of every single building. These models do not require any historical data as required by the top-down models and bottom-up statistical models, but require the knowledge of the building's physical parameters, including the building's shape, orientation, glazing, occupancy rates and schedule, envelope thermal properties, etc.

Several physics-based UBEM models have been proposed and applied in investigating urban building energy use in the past years. CitySim was developed by the Ecole Polytechnique Federale de Lausanne University in 2009, and it used a simplified thermal model to estimate urban building energy use at the district scale [31]. While the accuracy of the proposed CitySim is limited as a simplified model used in energy-use estimations, it still can provide decision support for energy-use management and greenhouse gas emission reduction. Reinhart et al. [32] developed an Urban Modeling Interface (UMI) in assessing building energy use performance, neighborhood walkability, and daylight potential under a Rhino-based environment. The sustainable design lab from the Massachusetts Institute of Technology proposed a UBEM model for the City of Boston in 2016. Specifically, the UBEM was developed based on GIS datasets and a custom-building archetype, and 83,541 buildings were generated using the CAD modelling and environment Rhinoceros 3D [4]. The model has been calibrated and validated and is capable of estimating city-wide building energy use at the building level and hourly scale. City Building Energy Saver (CityBES), a web-based city-scale energy-use simulation and management platform, was developed by the Lawrence Berkeley National Laboratory. In particular, CityGML, 
an open data model for the storage and exchange of virtual 3D city models, was adopted by the CityBES for simulating building energy use and creating 3D building energy-use visualization [15]. Li et al. [12] simulated building energy use of the City of Des Moines, IA, with the newly developed CityBEUM model. Specifically, the energy-use mapping has been improved to the building level and hourly scale. Moreover, they also reported significant underestimation of electricity consumption in the summer and gas consumption in the winter, as well as overestimation of gas use in the spring when applying the Typical Meteorological Year (TMY) data in the model calibration and building energy-use simulation. Therefore, they emphasized the importance of applying actual weather data in urban building energy-use simulation.

Nowadays, the physics-based UBEMs have been widely applied in supporting urban energy-use management and greenhouse gas emission reduction throughout the world, such as in Boston [4], Chicago [33], Lisbon [34], Kuwait [35], Cambridge [36], Des Moines [12], Arriyadh [37], etc. Numerous works have been conducted for New York City (NYC) as well. Specifically, Howard and Parshall [19] proposed a model of energy consumption for NYC at a parcel level. Scofield [38] analyzed the effect of certification on energy consumption in NYC. Ma and Cheng [39] applied a geographic information system integrated data mining technology framework for estimating building energy-use intensity for NYC at an urban scale. Olivo and Hamidi [40] analyzed the spatiotemporal variability of building energy use in NYC. However, most studies have been conducted at an urban scale or parcel scale, no study has been implemented at the building level yet. NYC, especially the Manhattan borough, is the most urbanized and populated area in the US, and NYC is facing a big challenge in reducing energy use and emissions. In April 2019, the Climate Mobilization Act, the most aggressive climate bill in the US, was passed by NYC to abide by the Paris climate change agreement, and NYC committed to reducing the carbon emission by $80 \%$ by 2050 . Buildings contribute to almost $70 \%$ of the energy use and carbon emissions in NYC, and to reach the proposed carbon emission reduction target, several benchmarks have been prescribed in the new "80-by-50" law. Some buildings are required to reach the reduction goal earlier and different building types are subject to a specific target. For instance, buildings with total areas over 25,000 square feet need to reduce the emissions by $40 \%$ by 2030 , and that is about 500,000 buildings in NYC. Therefore, an urban building energy-use model with a high spatial (building level) and temporal resolution (hourly scale) is essential for the city government and citizens in NYC for managing building energy use and implementing effective ways to reduce carbon emissions.

When implementing UBEM, weather data has been considered as one of the most important components, and most UBEM tools use the TMY weather data or the weather data from a local weather station in the model calibration and simulation. The importance of applying actual weather data in the model calibration and simulation has already been clarified by Li et al. [12]. However, actual weather data from local weather stations may still not be enough for urban building energy use as actual weather data is commonly collected from the weather station from the airport, which is usually distributed in rural areas and far away from the downtown area in a city. Therefore, the impacts from the local microclimate have not been considered in the actual weather data. Several studies reported that the local microclimate, such as the urban heat island effect, could increase the temperature of the city's downtown areas more than the surrounding rural areas [41]. Therefore, it will increase the use of air conditioning, which, in turn, has a positive feedback on the urban heat island effect. Instead of applying actual weather data, localized weather data is needed in the urban building energy calibration and simulation process.

In this study, I proposed a work to quantify the building energy use of Manhattan in NYC with consideration of the local microclimate by integrating two popular modeling platforms, the Urban Weather Generator (UWG) and UBEM. The UWG was developed by Bueno and Norford [42], and it can generate localized hourly weather data based on the referenced hourly weather data and local physical parameters. The UBEM has been widely used in many studies, and it is powerful in estimating building energy use at the building level and hourly scale. The paper is organized as follows: the study area, Manhattan in NYC, is introduced in Section 2. the UWG and UBEM are described in Section 3. 
The modeling results, including the spatial and temporal pattern of annual, monthly, and hourly building energy use, are reported in Section 4. Conclusions are included in Section 5.

\section{Study Area and Data}

The borough of Manhattan, situated in the northwest part of NYC, was chosen as the study area (Figure 1). Manhattan is one of the most urbanized and populated boroughs in NYC, with a population of 1.6 million in 2017 and a geographic area of $59.13 \mathrm{~km}^{2}$. Manhattan features a humid subtropical climate, the winter is cold and damp, and the summer is warm to hot and humid. Manhattan has been classified as Climate Zone 4A by the ASHRAE. Manhattan also suffers the urban heat island effect due to a high building density and little vegetation cover. The temperature difference between Manhattan and the surrounding areas could be up to $15^{\circ} \mathrm{C}$. Manhattan is mainly covered by commercial buildings (e.g., offices, retails, restaurants, hotels) and residential buildings (e.g., apartments and houses), and they are contributing around $70 \%$ of the energy use in Manhattan.
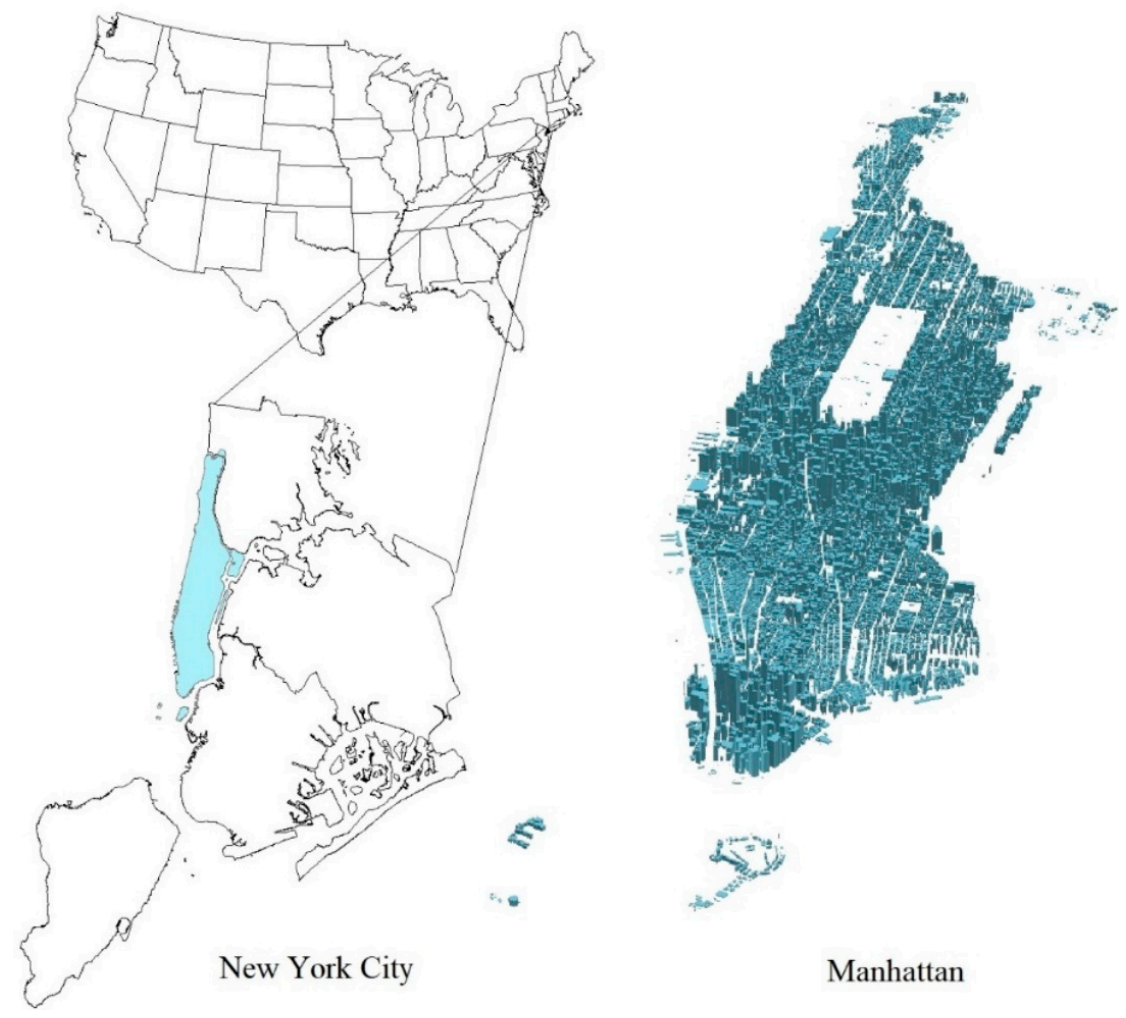

Figure 1. Study area: Manhattan, New York City, US.

To model the building energy use for the borough of Manhattan, several GIS data were collected from the New York City Open Data platform and the State of New York government website. Specifically, the GIS building footprint data, which include all city-wide building information, was collected from the New York Open Data Platform (https://opendata.cityofnewyork.us/). The building footprint data include accurate information about building construction year, number of floors, and building location. In addition, the land-use parcel data was obtained from the website of the State of New York government (http://gis.ny.gov/parcels/). It includes information about building type and building HVAC information. For model calibration and simulation purposes, the actual weather data at Central Park, Manhattan, in 2009 and 2012 were obtained from the Whitebox technique [43]. To calibrate the new model, the Residential Energy Consumption Survey (RECS) [44] and Commercial Buildings Energy Consumption Survey (CBECS) [45] in 2009 and 2012 were collected from the Energy Information Administration (EIA), respectively. 


\section{Methodology}

In order to quantify the building energy use in Manhattan, NYC, a new building energy-use model was constructed (Figure 2); it could be detailed using the following steps. Firstly, this study generated localized weather data based on existing hourly weather data and localized physical parameters using the Urban Weather Generator (UWG). Secondly, the UBEM was employed and calibrated for modeling the building energy use of Manhattan. Finally, the building energy consumption of Manhattan was simulated using the calibrated UBEM model and the localized weather data.

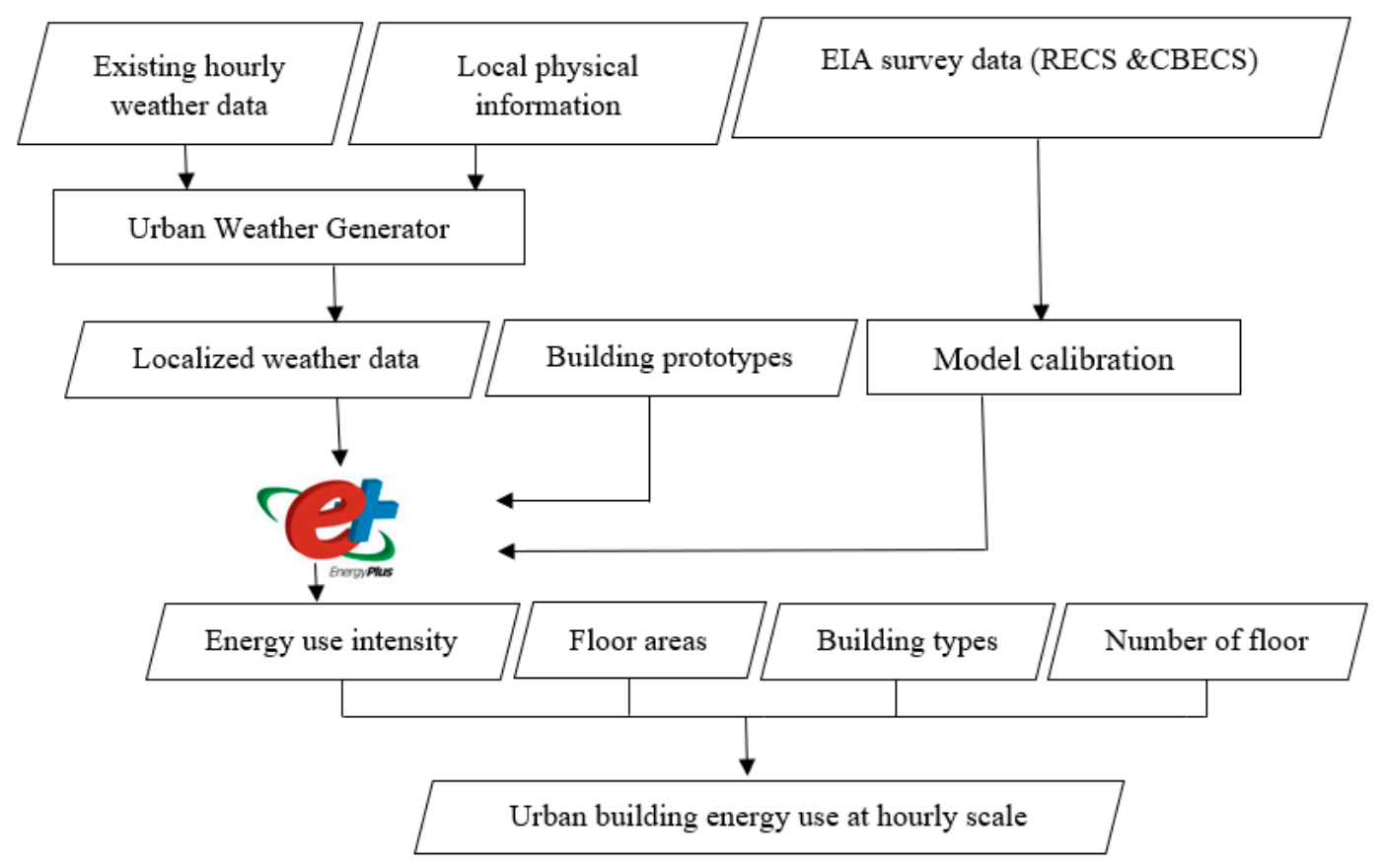

Figure 2. Flow chart of the proposed study.

\subsection{Generating Localized Weather Data}

The UWG is developed by Bueno et al. [42], and it can estimate hourly air temperature with consideration of the local microclimate based on the collected hourly weather data situated outside the city. It composes four modules: the rural station model, vertical diffusion model, the urban boundary layer model, and the urban canopy and building energy model. In UWG, the user can identify and describe an urban area geometrically through the average building height, horizontal building intensity, and vertical to horizontal urban area ratio. In general, users need to input the parameters into the UWG in four categories: geometric and local parameters, radiative parameters, thermal parameters, and building model parameters. Currently, the UWG has been updated to version 4.1 and could be requested from the website of the building technology program at MIT directly (https://urbanmicroclimate.scripts.mit.edu/uwg.php).

\subsection{Modelling Building Energy Use}

In this study, an urban building energy-use model (UBEM) was developed and used to model the building energy use of Manhattan. The UBEM modelled the city-wide building energy use by combing the building floor area, number of floors, and the modelled building energy-use intensity [12].

$$
E U_{j}=E U I_{m} \times F A_{j} \times N F_{j}
$$


where $E U_{j}$ is the simulated electricity or gas consumption for building $j, E U I_{m}$ is the electricity or gas use intensity for building type $\mathrm{m}, F A_{j}$ is the footprint area of building $j$, and $N F_{j}$ is the total amount of floors of building $j$.

The floor areas of the buildings were derived from the GIS database of the building footprints. To simulate building energy-use intensity, this study aggregated all buildings within the study area into twenty-eight commercial and six residential building prototypes [46,47] (Figure 3). Specifically, commercial buildings were categorized as hotel, primary school, secondary school, shopping mall, warehouse, retail store, supermarket, office, hospital, quick service restaurant, and full-service restaurant. They were further categorized based on the built year (pre-1980 or post-1980) as varied energy consumption for buildings constructed before and after 1980. Moreover, office buildings were reclassified as large $\left(>5110 \mathrm{~m}^{2}\right)$, medium $\left(511-5110 \mathrm{~m}^{2}\right)$, and small offices $\left(<511 \mathrm{~m}^{2}\right)$, based on the floor areas; hotel buildings were regrouped into two classes: large and small hotels, based on floor areas larger or smaller than $5110 \mathrm{~m}^{2}$. Residential buildings were classified as mid-rise apartments, single-family, and multiple-family. The mid-rise apartments were further subdivided into two classes based on the built year before or after 1980. Single-family and multi-family were subdivided into four types based on the primary heating methods: electrical heating or gas heating.

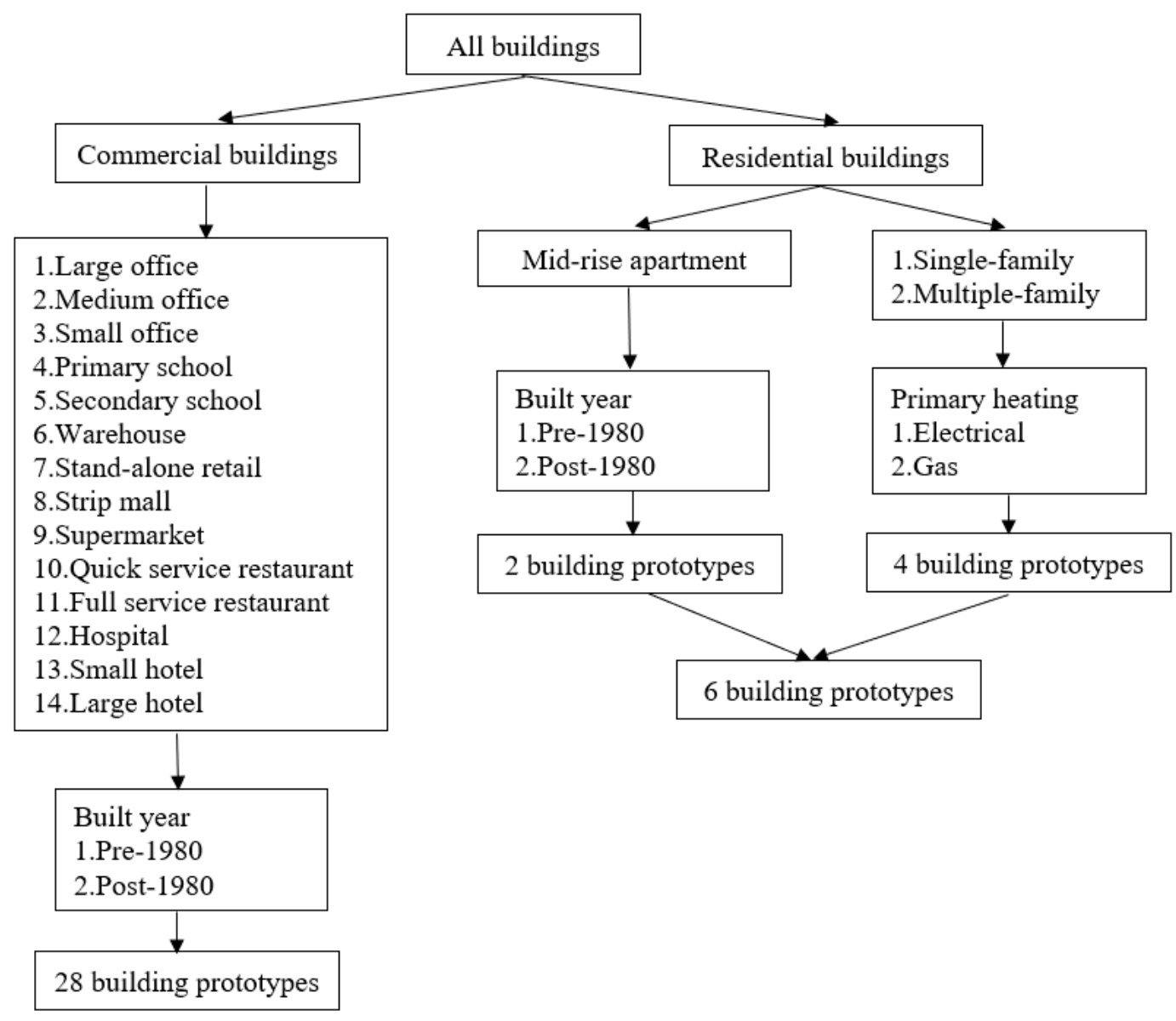

Figure 3. Building typology of the proposed study.

An engineering model, EnergyPlus v9.2, was employed to estimate the energy-use intensity for each building prototype. To establish the energy-use intensity model for each building prototype, the reference commercial and residential building models from the Department of Energy (DOE) and the Pacific Northwest National Laboratory (PNNL) were collected and used in this study. The commercial building models were developed by the DOE directly, and it covers different climate zones [47]. The residential building models were developed by the PNNL and governed by the DOE; the models 
are available for each state [46]. Specifically, the energy-use intensity model of the 28 commercial buildings and the mid-rise apartment buildings were obtained from the designed models of Baltimore developed by the DOE as NYC is situated in the same climate zone as Baltimore, and they also share similar building constructions. In addition, four residential building energy-use intensity models were collected from the designed models of NYC developed by the PNNL.

The thirty-four building energy-use models that were designed were calibrated for simulating the energy use of Manhattan. Model calibration is the key for energy-use simulation: Without calibration, the collected models may not be good enough for reflecting the actual building energy use as a discrepancy may exist between the collected models and the actual practical operation. We first updated most of the local parameters, such as latitude, longitude, and elevation, in the models, and then we calibrated the models through adjusting the buildings' internal information, such as lighting intensity, electric equipment consumption intensity, and occupancy schedule, to minimize the difference between the simulated results and the reference data. In this study, we calibrated all models using the US EIA's RECS and CBECS data in 2009 and 2012, respectively.

\section{Results and Discussion}

\subsection{Localized Weather Data Generated by UWG}

The Urban Weather Generator was developed by the MIT, with the actual weather data from weather stations in rural areas and with localized physical parameters input; the UWG can revise the actual weather data with consideration of the variations of the local environment. There are several physical parameters that need to be included in the UWG, such as location, latitude, longitude, city diameter, average building height, horizontal building density, wall construction, wall albedo, building glazing ratio, building window construction, building cooling and heating system, the surface albedo of weather station, and the vegetated faction of the weather station. The generated local weather data and the differences between the generated weather data and the weather data from the weather stations are included in Figure 4. It shows that urban temperatures are much higher than the temperature observed from the surrounding rural areas, and the differences are much higher in the summer. It is consistent with our knowledge that the urban heat island effect can increase the temperature in the downtown area, and such an increased temperature will definitely cause a much higher cooling demand for buildings in the downtown area.

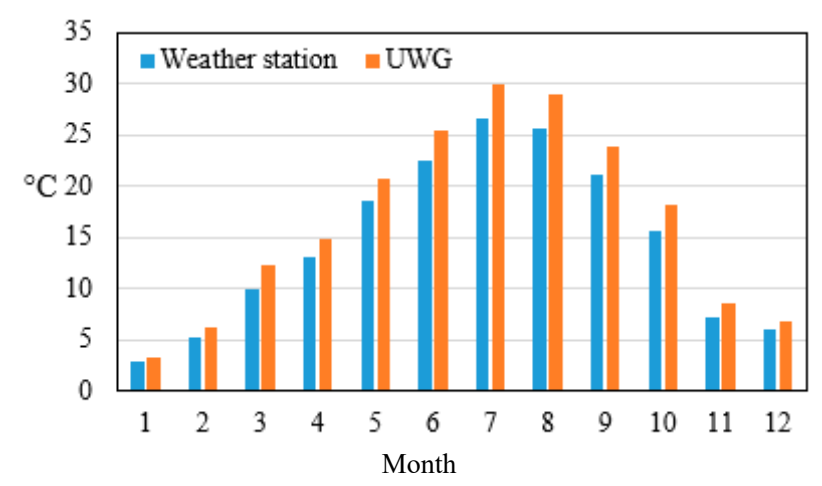

Figure 4. Localized monthly average based on hourly temperature.

\subsection{Building Energy Use of Manhattan Simulated by UBEM}

\subsubsection{UBEM Input}

To run the UBEM, to quantify the building energy use of Manhattan, NYC, several pieces of important information need to be put into the model. In this study, most parameters were collected from the technical report of the US Department of Energy Reference Building Models of the National Building 
Stock provided by the National Renewable Energy Laboratory, to represent a typical performance of the different building types [48]. In general, the model input could be listed as program, form, fabric, and equipment (see Table 1.). Occupancy is one of the most important parameters in the model; it can be collected from different sources, such as CBECS, RECS, and ASHRAE. In this study, the occupancy rates for all the reference building models were collected from Standard 62.2 from ASHRAE. Table 2 lists the occupancy rate by space types, and most buildings are composed of one or more of the space types listed below. Ventilation/Outside air (OA) requirements are included in Table 3 by space types, and they are also collected using Standard 62 from ASHRAE. As limited information is available for old buildings, this study assumes all reference buildings are having the same ventilation requirements, and a reevaluation is expected when more information is available in the future. The occupancy schedule was applied with Standard 90.1 from ASHRAE. Different building types have quite different schedules. For instance, a restaurant may have a kitchen electric (gas) equipment schedule and dining area schedule. A hospital has an administrative area schedule, ER schedule, lab schedule, inpatient area schedule, and outpatient schedule. Residential buildings have a kitchen schedule, dining room schedule, and bedroom schedule. In general, some schedules are included in most building models, such as a building occupancy schedule, building the electric equipment schedule, and the HAVC system schedule (including both cooling and heating systems). All the occupancy schedules can also be divided as a weekday schedule, weekend schedule, and holiday schedule. Figure 5 shows the general weekday building occupancy schedules of the different building types. Due to the different functions they have, quite different hourly patterns could be found. The model input is the first and one of the most important steps for establishing the building energy-use model; more input parameter information could also be found from the technical report of the US Department of Energy Reference Building Models of the National Building Stock provided by the National Renewable Energy Laboratory [48].

Table 1. The general model input information [48].

\begin{tabular}{llll}
\hline Program & Form & Fabric & Equipment \\
\hline Ventilation requirements & Orientation & Roof & Lighting \\
Service hot water demand & Floor height & Floors & Efficiency \\
Operating schedules & Shading & Windows & HVAC system \\
Total floor area & Window location & Infiltration & Water heating \\
Occupancy & Number of floors & Wall & Control settings \\
\hline
\end{tabular}

Table 2. Occupancy by space type [48].

\begin{tabular}{|c|c|c|c|c|}
\hline \multirow{2}{*}{ Space Type } & \multicolumn{2}{|c|}{ Occupancy } & \multirow{2}{*}{ Space Type } & Occupancy \\
\hline & per space & $\mathrm{m}^{2} /$ person & & $\mathrm{m}^{2} /$ person \\
\hline Apartment & 3 & & Supermarket & 11.6 \\
\hline Fast food dinning & & 1.4 & Hospital (ER) & 4.7 \\
\hline Classrooms & & 4 & Hospital (lab) & 18.6 \\
\hline Corridor (school) & & 10 & Hospital (ICU) & 4.7 \\
\hline Hotel guest room & 1.5 & & Warehouse & 0 \\
\hline Lobby (hotel) & & 3 & Office (school) & 20 \\
\hline Office & & 18.6 & Library & 4.4 \\
\hline Restaurant & & 1.4 & Restroom (school) & 100 \\
\hline Sales & & 6.2 & Reception areas & 3.1 \\
\hline Storage & & 28 & Lobby (office building) & 9.3 \\
\hline
\end{tabular}


Table 3. Outside air requirements (ventilation) [48].

\begin{tabular}{|c|c|c|c|}
\hline \multirow{2}{*}{ Space Type } & \multicolumn{2}{|c|}{ OA } & \multirow{2}{*}{$\frac{\text { Total OA }}{\mathrm{L} / \mathrm{s} / \mathrm{m}^{2}}$} \\
\hline & $\mathrm{L} / \mathrm{s} /$ person & $\mathrm{L} / \mathrm{s} / \mathrm{m}^{2}$ & \\
\hline \multicolumn{4}{|l|}{ Apartment } \\
\hline Fast food dinning & 9.44 & & 6.77 \\
\hline Classrooms & 7.08 & & 1.77 \\
\hline Corridor (school) & & 0.51 & 0.51 \\
\hline Hotel guest room (cfm/room) & 14.16 & & \\
\hline Lobby (hotel) & 9.44 & & 3.05 \\
\hline Office & 9.44 & & 0.51 \\
\hline Restaurant & 9.44 & & 6.77 \\
\hline Sales & & 1.52 & 1.52 \\
\hline Storage & & 0.76 & 0.76 \\
\hline Supermarket & 7.08 & & 0.61 \\
\hline \multicolumn{4}{|l|}{ Hospital (ER) } \\
\hline \multicolumn{4}{|l|}{ Hospital (lab) } \\
\hline \multicolumn{4}{|l|}{ Hospital (ICU) } \\
\hline Warehouse & & 0.25 & 0.25 \\
\hline \multicolumn{4}{|l|}{ Office (school) } \\
\hline \multicolumn{4}{|l|}{ Library } \\
\hline Restroom (school) & 23.6 & & \\
\hline Reception areas & 7.08 & & 2.29 \\
\hline Lobby (office building) & 9.44 & & 1.02 \\
\hline
\end{tabular}
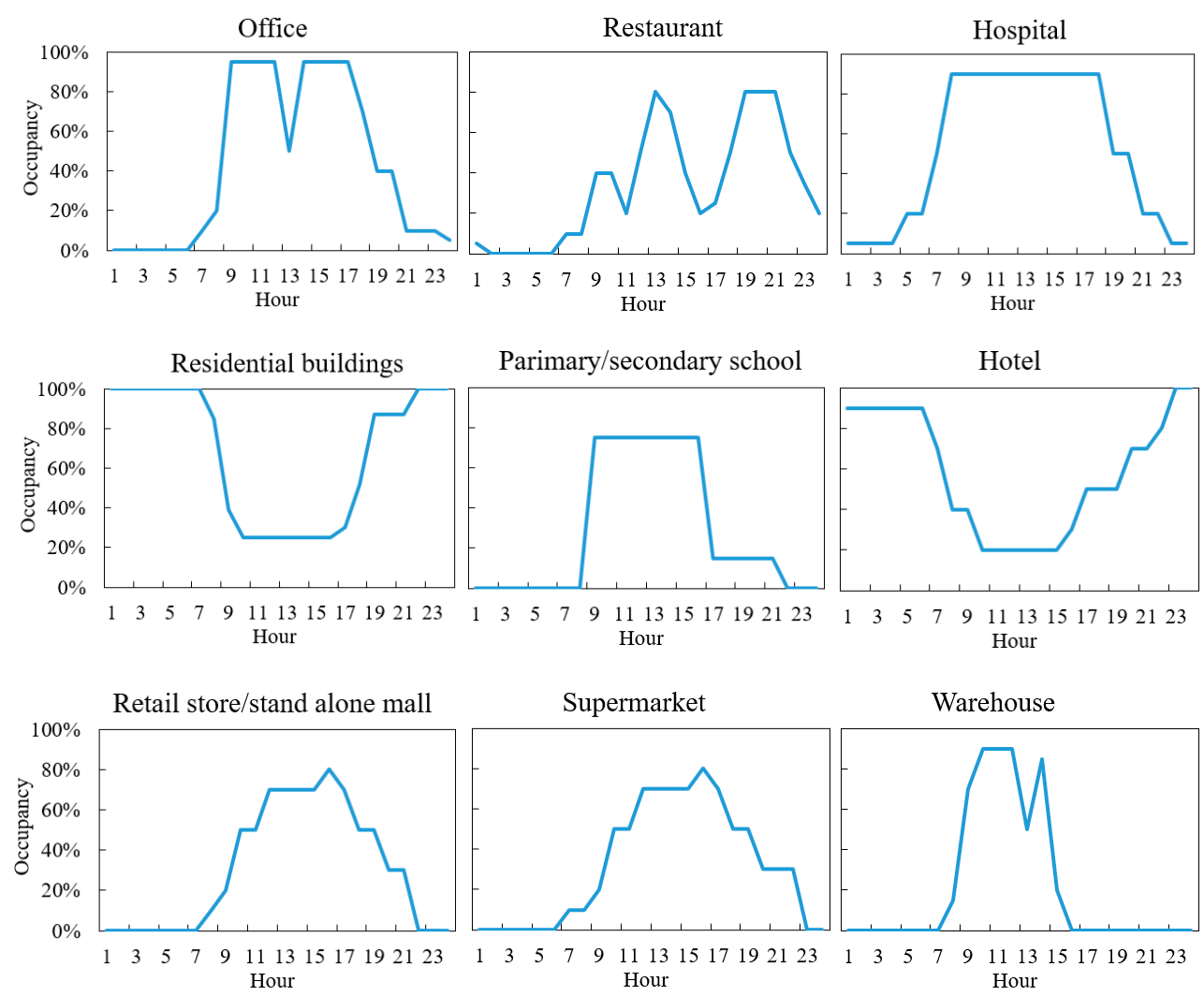

Figure 5. Building weekday hourly occupancy schedules.

\subsubsection{UBEM Calibration}

With the established UBEM model, the hourly energy-use intensity of all the designed building prototypes could be calculated. To further apply the simulated results for the final building energy-use calculation, the model calibration needs to be implemented first. In this study, the energy-use reference 
data from RECS and CBECS, including electricity and gas consumption data, were collected from the EIA for model calibration. RECS and CBECS are the only two nationwide statistical information sets on building energy consumption. RECS and CBECS data are collected in two phases: Phase 1 is the building survey, which collects basic information about the buildings, such as structural characteristics, building size, building type, and energy-use equipment; Phase 2 is the energy consumption survey that collects, through a website or mail, the basic energy-use information, such as electricity consumption, gas consumption, and heating oil consumption. The RECS and CBECS data are widely used by building managers, energy modelers, government leaders, and the Energy Star program. There are more than 1000 itemized information about buildings and their associated energy-use information included in the RECS and CBECS data sets. Selected important building and energy-use information is listed in Table 4. For instance, primary and more specific building activity delivers information about building types; construction year could help to separate the reference data into two categories, pre- 1980 built buildings and post-1980 built buildings; the number of floors and building footprint helps the calculation of the referenced energy-use intensity; and electricity and gas consumption deliver direct information about the building's energy-use amount. With the all-important building and corresponding energy-use information listed in Table 4, the referenced building energy-use intensity for all 34 building types was calculated and used for further model calibration.

Table 4. Building and energy-use information included in RECS and CBECS.

\begin{tabular}{lll}
\hline General Information & Building Typology & Energy Use \\
\hline Census region & Number of floors & Electricity used \\
Construction year & Main heating equipment & Natural gas used \\
Primary building activity & Main cooling equipment & Electricity used for cooling \\
Final full sample building weight & Water heating equipment & Gas used for heating \\
More specific building activity & Building footprint (area) & \\
\hline
\end{tabular}

To minimize the discrepancy between the modeled energy-use intensity and actual energy-use intensity, several important building parameters, such as the set point, occupancy schedule, usage pattern, etc., have all been optimized. Specifically, the setpoint of the cooling and heating system is very essential in modeling building energy use. Different building types may have a significantly varied cooling and heating demand. In this study, the minimum acceptable room temperature and the optimum room temperature in the summer from the engineering toolbox [49] were collected and used as reference data for adjusting the cooling and heating set point of the HVAC system in the model calibration (see Table 5). Table 5 shows that the accepted room temperature in winter for the school (classroom or lecture room) is $20^{\circ} \mathrm{C}$; the hotel is $21^{\circ} \mathrm{C}$; the office is $20^{\circ} \mathrm{C}$; the restaurant is $18^{\circ} \mathrm{C}$; and warehouse is $16^{\circ} \mathrm{C}$. Moreover, the general optimum room temperature in the summer is between $20^{\circ} \mathrm{C}$ and $22^{\circ} \mathrm{C}$ for most rooms. Therefore, when the calibration is conducted, the cooling and heating set point of the HVAC system has to be set with the consideration of the recommended room temperatures. Moreover, the occupancy schedule is another very important parameter. Business buildings, school buildings, and residential buildings may have different schedules. People may have different timing for getting up, leaving home, starting work or study, going back home, or going to bed. Therefore, different schedules must be considered for different buildings. In this study, the most optimum building occupancy schedule (Figure 5) recommended by the technical report of the US Department of Energy Reference Building Models of the National Building Stock provided by the National Renewable Energy Laboratory was applied. Furthermore, schools may have spring, summer, fall, and winter breaks, which result in lower energy consumption. They all must be considered in the schedule section during model calibration. The primary school and secondary school operating schedules were collected from the Department of Education in New York City [50]. It shows the spring semester starts in late January and ends in late June, and the fall semester starts in early September 
and ends in late December. Therefore, the summer break (July and August) and spring break (January) were set as time points of limited operation with relatively low energy consumption [50].

Table 5. The minimum acceptable room temperature in the winter and the optimal room temperature in the summer of different room types [49].

\begin{tabular}{ccccc}
\hline Season & Room Type & Temperature $\left({ }^{\circ} \mathbf{C}\right)$ & Room Type & Temperature $\left({ }^{\circ} \mathbf{C}\right)$ \\
\hline \multirow{5}{*}{ Winter } & Bathrooms & 22 & Lecture rooms & 20 \\
& Bedrooms & 18 & Libraries & 20 \\
& Classrooms & 20 & Living rooms & 21 \\
& Corridors & 16 & Offices & 20 \\
& Dining rooms & 20 & Recreation rooms & 18 \\
& Exhibition halls & 18 & Restaurants & 18 \\
& Hotel rooms & 21 & Shops & 18 \\
& Laboratories & 20 & Stores & 15 \\
& Wards & 18 & Warehouses & 16 \\
\hline \multirow{2}{*}{ Summer } & All rooms & $20-22$ & & \\
\hline
\end{tabular}

In addition, both electricity and gas consumption are coming from different components, such as lighting, cooking, heating, cooling, refrigerator, machines in the lab, machines in the office, etc. In general, one or more listed lighting, electric, and gas equipment are included in each specific building type (see Table 6). For instance, schools may include lighting, electric equipment, and gas equipment for a dorm, classroom, lab, cafeteria, library, and auditorium. The office only has office lights and corridor lights in lighting, electric equipment for the office, meeting room, and employee lounge, and no gas equipment. Residential buildings include more specific equipment, such as a refrigerator, microwave, laundry machine, TV set, stove for cooking, and lighting in different rooms. In this study, the reference data collected from the Pacific Northwest National Lab were used for updating all models for model calibration purposes [51]. In summary, energy plus has hundreds of parameters. On the one hand, it is impossible for us to make the change for all parameters; on the other hand, not all reference data are available to be used for the calibration. Therefore, the goal of the model calibration is to minimize the discrepancy between the modeled results and the referenced number with the available reference information.

Table 6. Selected lighting, electric, and gas equipment inside buildings.

\begin{tabular}{lll}
\hline Lighting & Electric Equipment & Gas Equipment \\
\hline Dinning lights, kitchen lights & Dining room equipment & Kitchen cooking equipment \\
Lab lights, ER lights, office lights & Nurse station equipment & Water heating furnace \\
Corridor lights, apartment lights & Kitchen room equipment & Heating (HVAC) equipment \\
Bathroom lights, auditorium lights & Auditorium equipment & Laundry equipment \\
Cafeteria lights, gym lights & Cafeteria equipment & \\
Library lights, classroom lights & Library equipment & \\
Guest room lights, employee lounge lights & Employee lounge equipment \\
Admin office lights & Meeting room equipment & \\
Restroom lights, deli lights & Guest room equipment \\
Produce lights & Laundry room equipment & \\
sales lights & Refrigerator (residential) & \\
storage room lights & Microwave (residential) & \\
\hline
\end{tabular}

Figure 6 indicates that, after calibration, the difference between the simulated electricity- and gas-use intensity and the actual energy-use intensity were all reaching the evaluation criteria (within $\pm 10 \%$ ). Therefore, all the proposed energy-use intensity models are qualified to estimate the actual energy-use intensity of all the building prototypes. The annual energy-use intensity included in Figure 6 shows that for commercial buildings, the quick-service restaurant has the highest energy-use intensity for electricity consumption and the full-service restaurant has the highest energy-use intensity 
for gas consumption. Moreover, the warehouse has the lowest electricity- and gas-use intensity. In terms of residential buildings, the multi-family residences have a much higher electricity- and gas-use intensity than single-family residences. After model calibration, the modeled total electricity and gas consumption in Manhattan was also compared with the real energy-use information from the City of New York, to make sure the modeled energy consumption is reasonable.
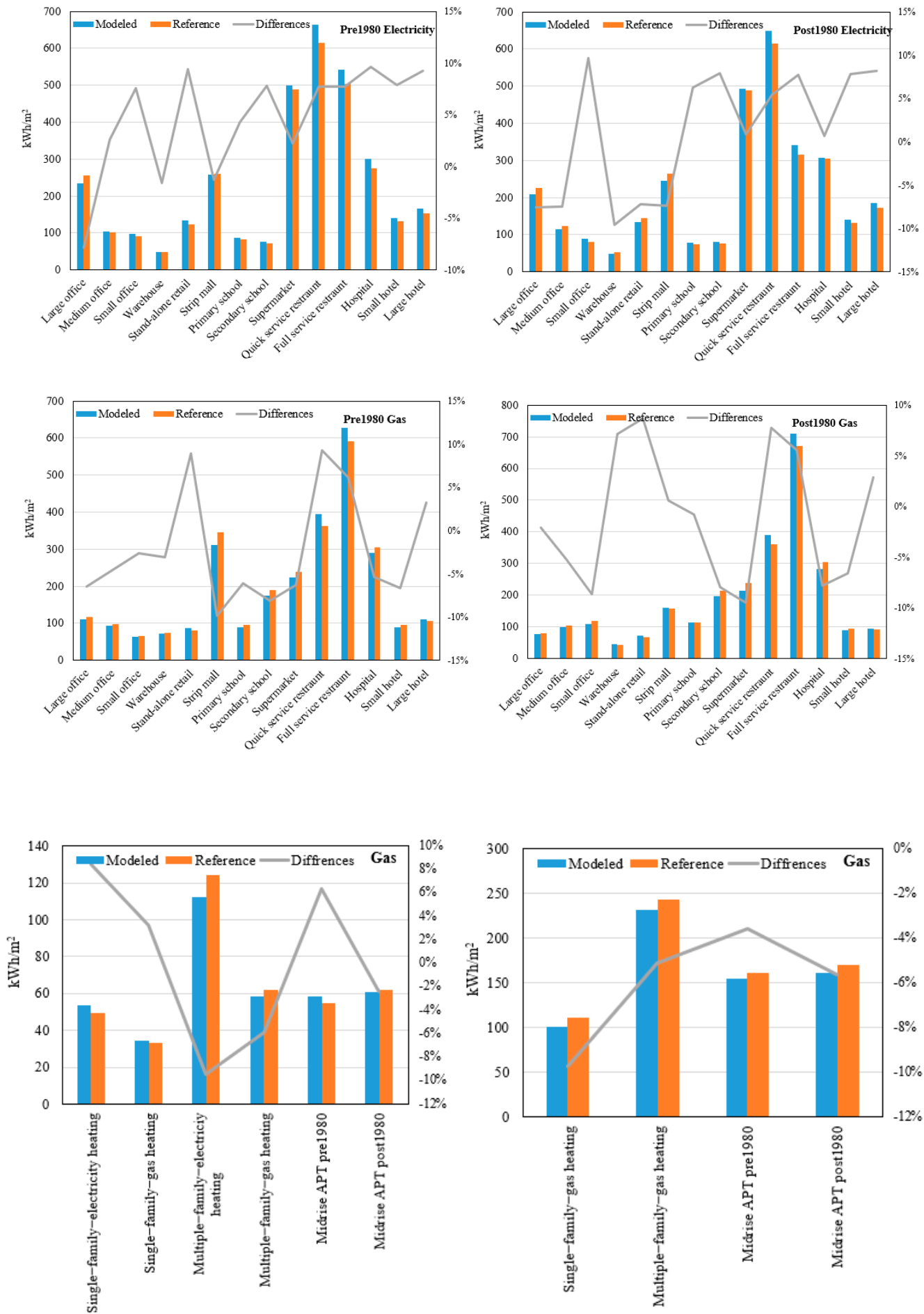

Figure 6. Comparison of the modeled and referenced energy-use intensity for residential and commercial buildings. 


\subsubsection{The Spatial Distribution of Energy Consumption in Manhattan}

Figure 7 shows the spatial distribution patterns of energy-use intensity in Manhattan, and quite different spatial patterns could be found between electricity-use intensity and gas-use intensity. Specifically, the highest electricity-use intensity is located in the center and southern corner of Manhattan, which are mainly composed of large offices with an annual electricity-use intensity over $200 \mathrm{kWh} / \mathrm{m}^{2}$. From the central area to the outlier of Manhattan, the electricity-use intensity drops significantly to around $100 \mathrm{kWh} / \mathrm{m}^{2}$, or even much lower as most buildings clustered here are medium offices, small offices, primary schools, secondary schools, retail stores, single-family houses, and midrise apartments. Moreover, some buildings, such as quick-service restaurants, full-service restaurants, and supermarkets, are dispersed in Manhattan with a much higher electricity-use intensity, around $500 \mathrm{kWh} / \mathrm{m}^{2}$. In contrast, quite different gas-use intensity patterns could be found in Manhattan. A very similar gas-use intensity could be found throughout Manhattan. Manhattan is very cold in the winter, gas is majorly used for heating purposes in the winter, and most buildings have a very similar gas-use intensity. Only some buildings located in the center and southern corner of Manhattan show a relatively lower gas-use intensity, which is mainly composed of large offices built after 1980 with improved energy-use efficiency. There are also some red spots with a high gas-use intensity dispersed in Manhattan, which is mainly composed of restaurants. With the modeled energy-use intensity of all the designed building prototypes, the building energy consumption could be quantified for all buildings in Manhattan through combing the corresponding building floor areas and number of floors information. The modeled building energy use is very straightforward as the total energy use was calculated for each building, and it is highly associated with building height. The energy use of Manhattan is progressively decreasing from the urban core, which is mainly covered by commercial buildings such as offices, hotels, and retail stores, to suburban areas, which are mainly composed of residential buildings (mostly apartments, single-family, and multi-family houses).
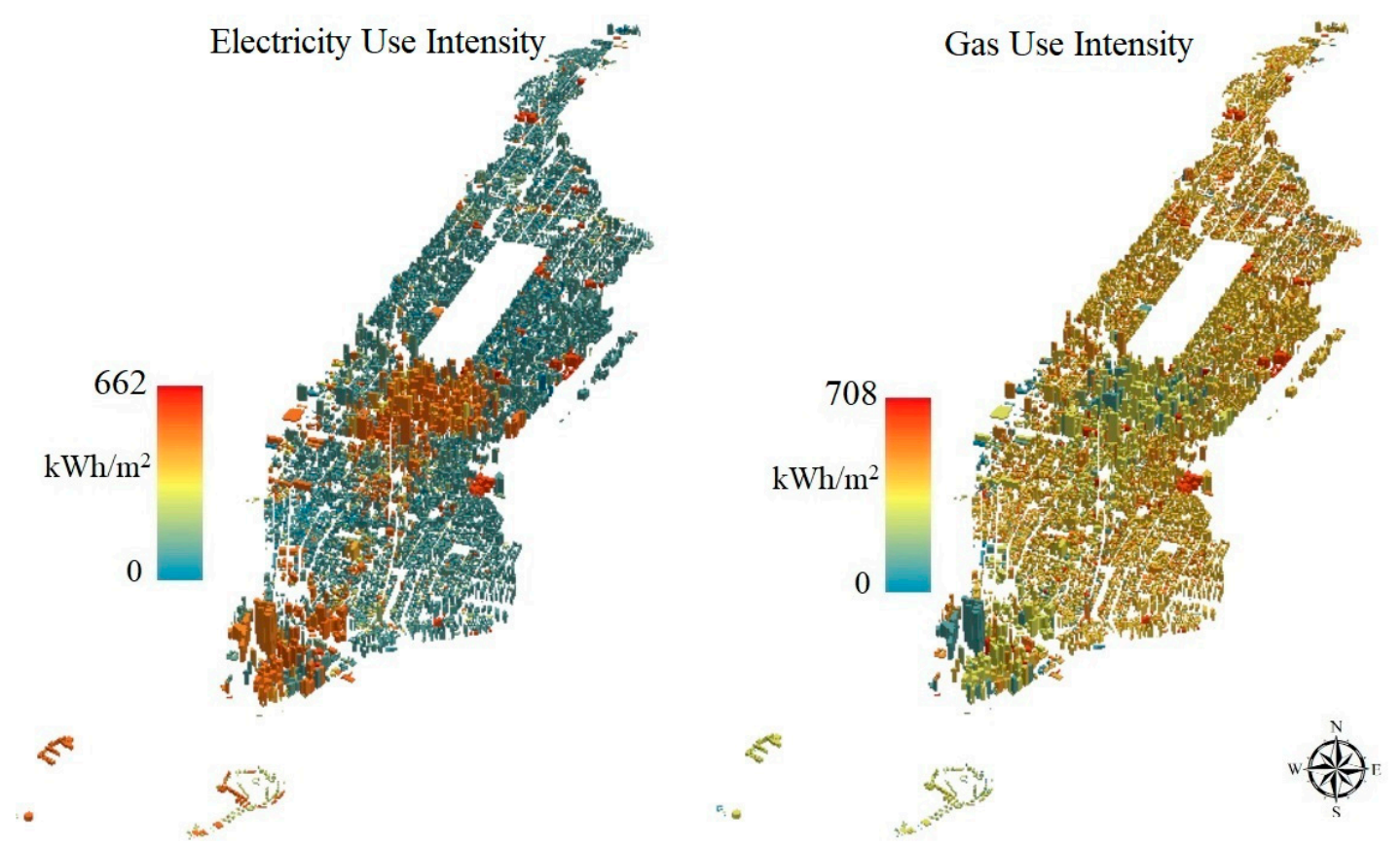

Figure 7. Modeled annual building electricity- and gas-use intensity in Manhattan, NYC, in 2012.

\subsection{The Temporal Profiles of Energy Consumption in Manhattan}

Figure 8 illustrates similar seasonal electricity-use intensity patterns but different seasonal gas-use intensity patterns. Specifically, the electricity-use intensity is very similar in four seasons except in summer. In addition to the general electricity use, electricity for cooling purposes is another major 
electricity consumption source in the summer. Therefore, a slight electricity-use intensity increase could be found in the summer. Significantly different seasonal gas-use intensity patterns could be found for Manhattan. In particular, gas-use intensity is the highest in the winter for heating purposes and much lower in the other three seasons. Moreover, spatially varied patterns of gas-use intensity could also be found in Figure 8. The central area and southern corner of Manhattan have a little bit lower gas-use intensity in the winter as some buildings are renovated with improved HVAC systems or built after 1980 with improved energy-use efficiency.

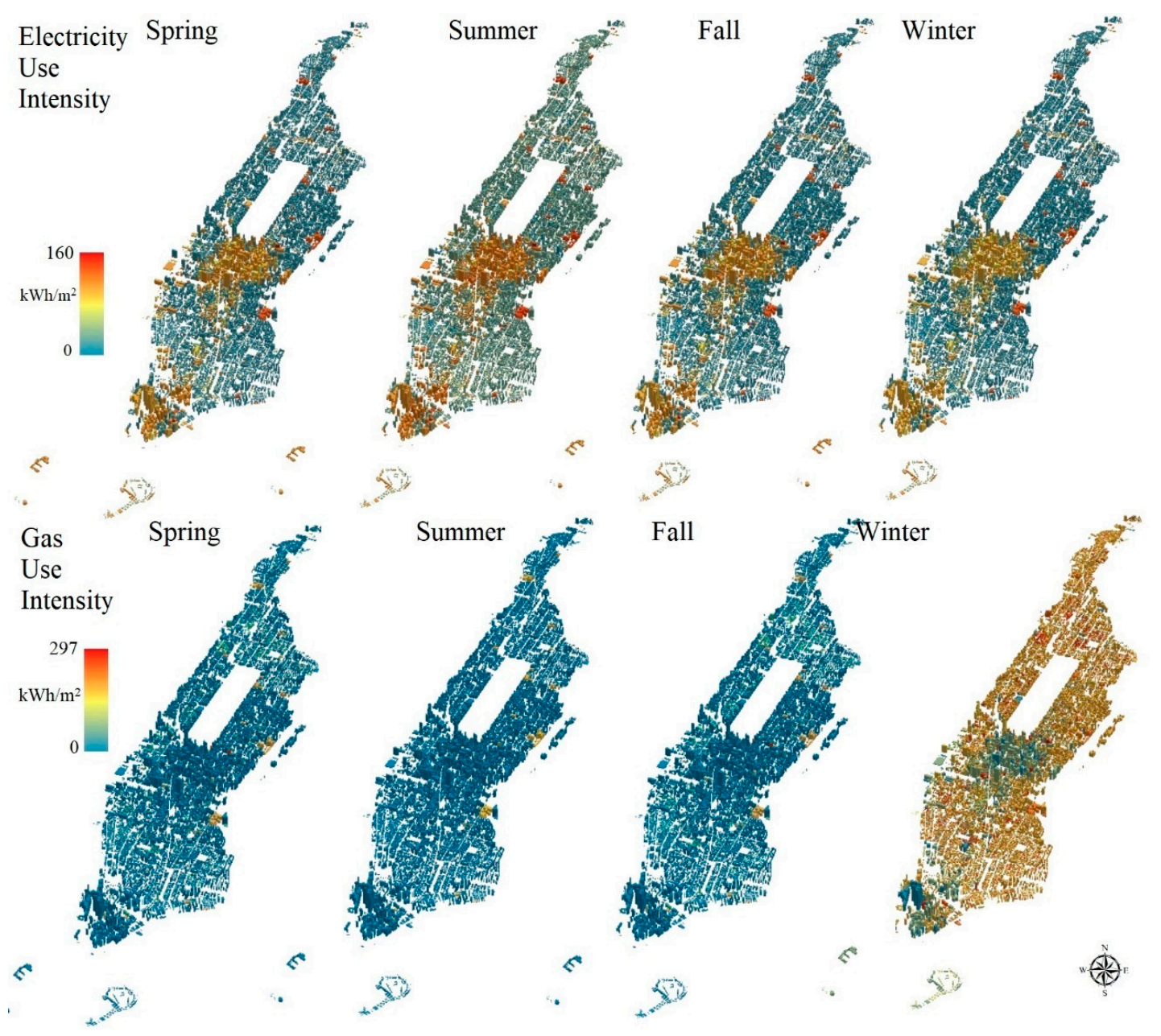

Figure 8. Seasonal energy-use intensity in Manhattan, NYC, in 2012.

To examine the monthly profiles of the building energy use in Manhattan, I aggregated the hourly electricity and gas consumption to the monthly scale. Figure 9 illustrates strong monthly electricityand gas-use variations. Both residential and commercial buildings show only one peak for both electricity and gas consumption in 2012. Specifically, the peak of electricity use is in the summer (around July and August) due to high cooling demand, and the peak of gas consumption is in the winter (around December and January) owing to high heating demand. In particular, the electricity use is stable from January to April and October to December; it starts jumping up in May, reaching the peak in July and August owing to high cooling demand, and finally drops in September. The gas consumption is relatively stable from May to September but starts jumping in October, reaching a peak in December and January due to high heating demand, and finally drops in April. 
Monthly Residential Energy Use in 2012

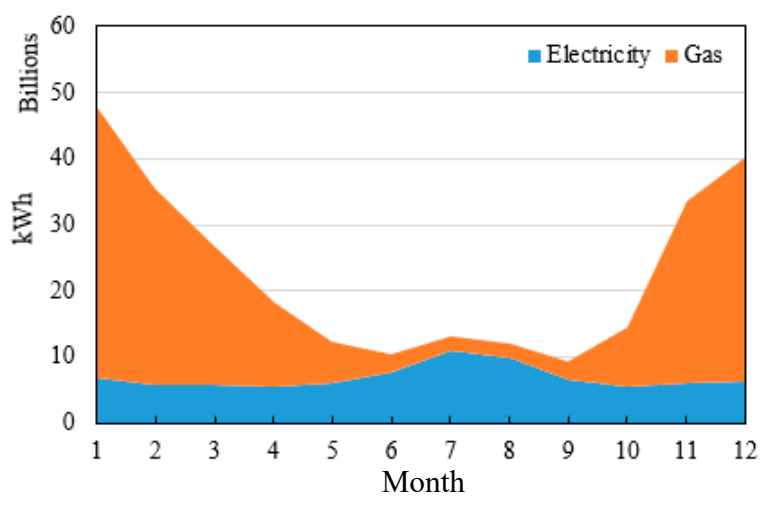

Monthly Commercial Energy Use in 2012

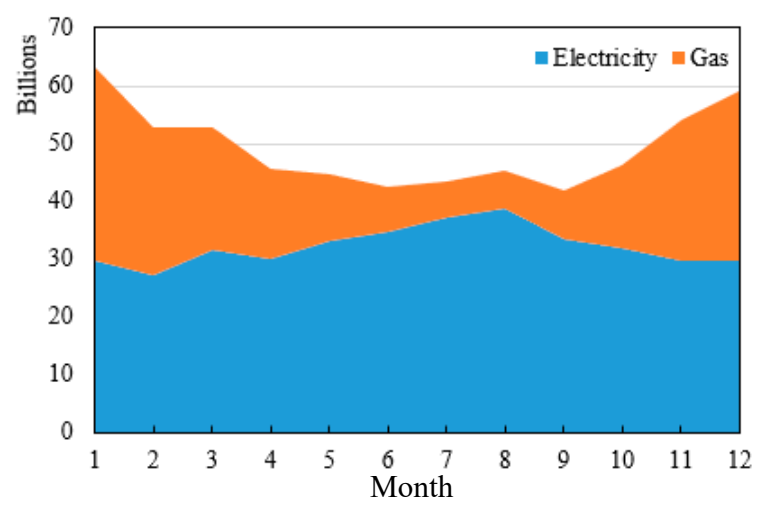

Figure 9. Monthly electricity and gas consumption in Manhattan in 2012.

Figures 10 and 11 illustrate hourly building energy use and energy-use intensity for the hottest (07-18-2012) and coldest (01-04-2012) days in Manhattan in 2012. The summer energy-use profiles show only one peak around noon, and the summer peak is mainly contributed by the high cooling demand from both residential and commercial buildings as it is the hottest time during a day. It is very consistent with the hourly building occupancy schedule provided in Figure 5 and hourly energy-use intensity provided in Figure 11. Most buildings such as offices, schools, retail stores, and supermarkets are opening around 7 or 8 a.m. in the morning, with the highest occupancy around noon from 11 a.m. to 1 p.m. The summer energy-use peak is contributed by both high building occupancy and high outside temperature. Figure 10 also shows a low demand for gas consumption as gas is only used for water heating at this time. In winter, energy consumption is much higher than in the summer. Two peaks could be found in Figures 10 and 11, with one significant peak in the morning and another peak in the evening. The first peak is mainly caused by high heating demand from commercial buildings. The residential building occupancy in Figure 5 shows that people are leaving home around 7 a.m. and most commercial buildings, such as offices, retail stores, and supermarkets, open at 7 or 8 a.m. It does support the conclusion that the first-morning energy-use peak is caused by high heating demand in the morning. The second peak is mainly contributed by residential buildings, as illustrated in Figure 5 , in that people finish their work and return home around 6 p.m., and a high heating demand was caused by low outside temperatures.

Figure 11 also shows the improvement in energy-use efficiency for buildings built after 1980 . Significant energy-use reduction could be found for some specific building types. For building electricity consumption, the strip mall, large office, and secondary school have all been improved significantly. The peak electricity-use intensity of strip mall, large office, and secondary school drops from around $0.09 \mathrm{kWh} / \mathrm{m}^{2}$ to around $0.08 \mathrm{kWh} / \mathrm{m}^{2}$, around $0.06 \mathrm{kWh} / \mathrm{m}^{2}$ to $0.05 \mathrm{kWh} / \mathrm{m}^{2}$, and around $0.04 \mathrm{kWh} / \mathrm{m}^{2}$ to $0.02 \mathrm{kWh} / \mathrm{m}^{2}$, respectively. Moreover, the efficiency of gas consumption was also improved. The peak gas-use intensity of the secondary schools also drops from around $0.25 \mathrm{kWh} / \mathrm{m}^{2}$ to $0.19 \mathrm{kWh} / \mathrm{m}^{2}$, and the peak gas-use intensity of the strip malls drops from $0.3 \mathrm{kWh} / \mathrm{m}^{2}$ to $0.2 \mathrm{kWh} / \mathrm{m}^{2}$. A similar situation could also be detected in Figure 9 for other building types. In summary, the energy-use efficiency of buildings built after 1980 has been improved significantly. 

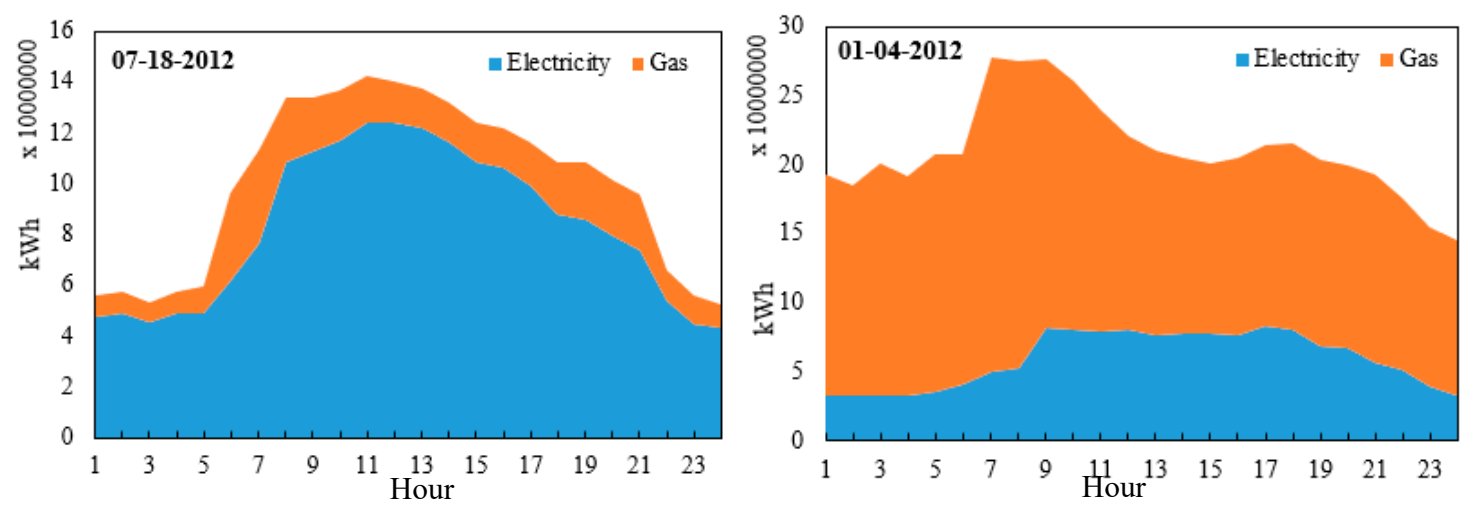

Figure 10. Hourly building energy use for summer and winter peak days.
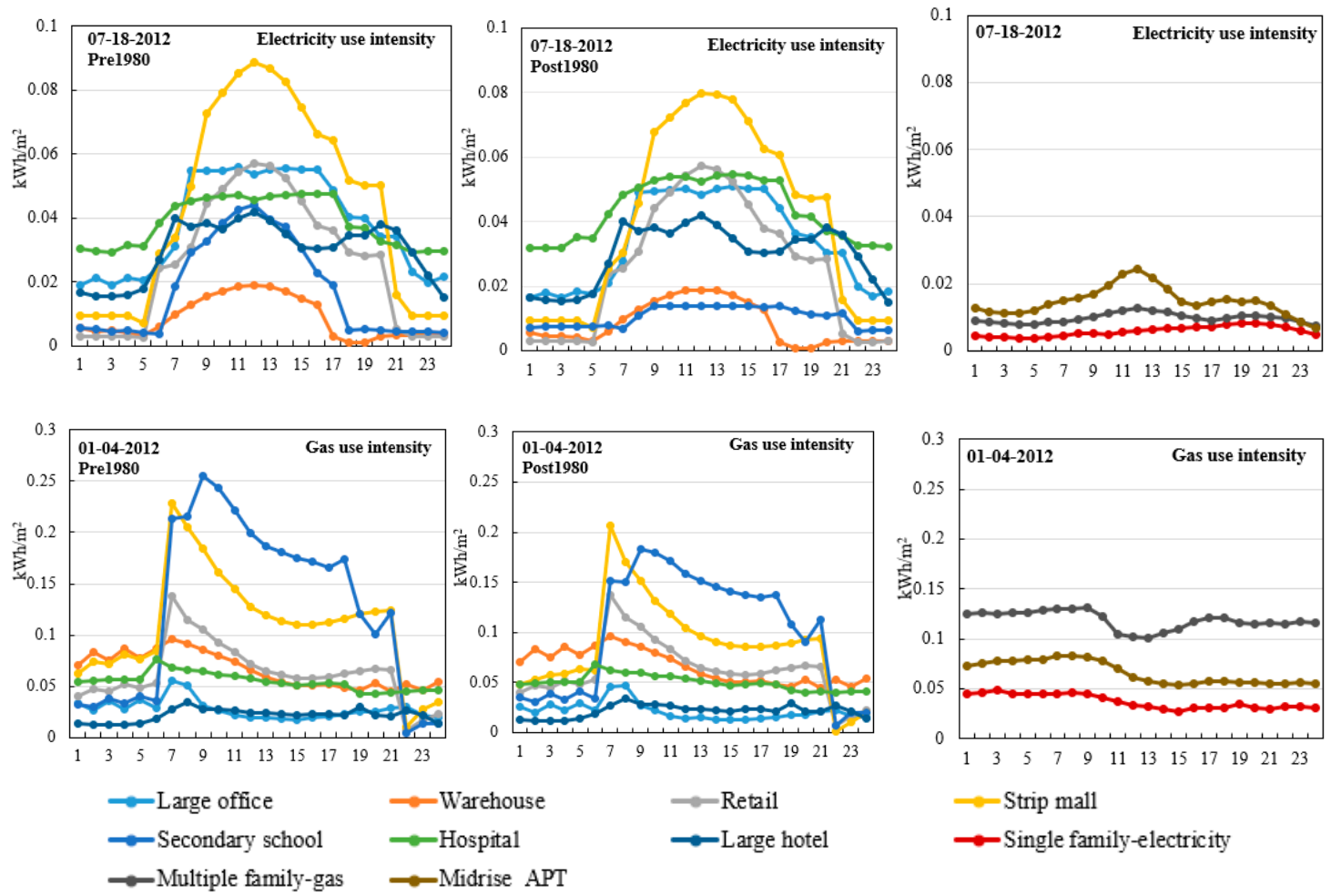

Figure 11. Hourly energy-use intensity (major building types) in Manhattan, NYC.

\subsection{Sensitivity Analysis}

Figure 12 illustrates the significant differences in building energy use between applying the TMY weather data and the localized weather data. In particular, residential buildings have a much higher electricity consumption in the summer and lower gas consumption in the winter in 2012 compared to the TMY as the temperature in 2012 was much higher than in other years. When the TMY weather data are applied, significant underestimation of electricity consumption (up to 16\%) and overestimation of gas consumption (up to $24 \%$ ) occur, due to underestimating the cooling demand and overestimating the heating demand. Similar patterns could also be found for commercial buildings. The application of TMY weather data in building energy modeling could result in underestimation of electricity use (up to $18 \%$ ) in the summer and overestimation of gas consumption (up to $21 \%$ ) in the winter, as there is unreasonable cooling and heating demand generated by the TMY weather data. In summary, electricity consumption for cooling and gas consumption for heating are all very important components of building energy consumption. When inappropriate weather data are applied, the building energy consumption will be highly misunderstood. Therefore, it is important to generate and apply localized weather data in building energy-use modeling. 

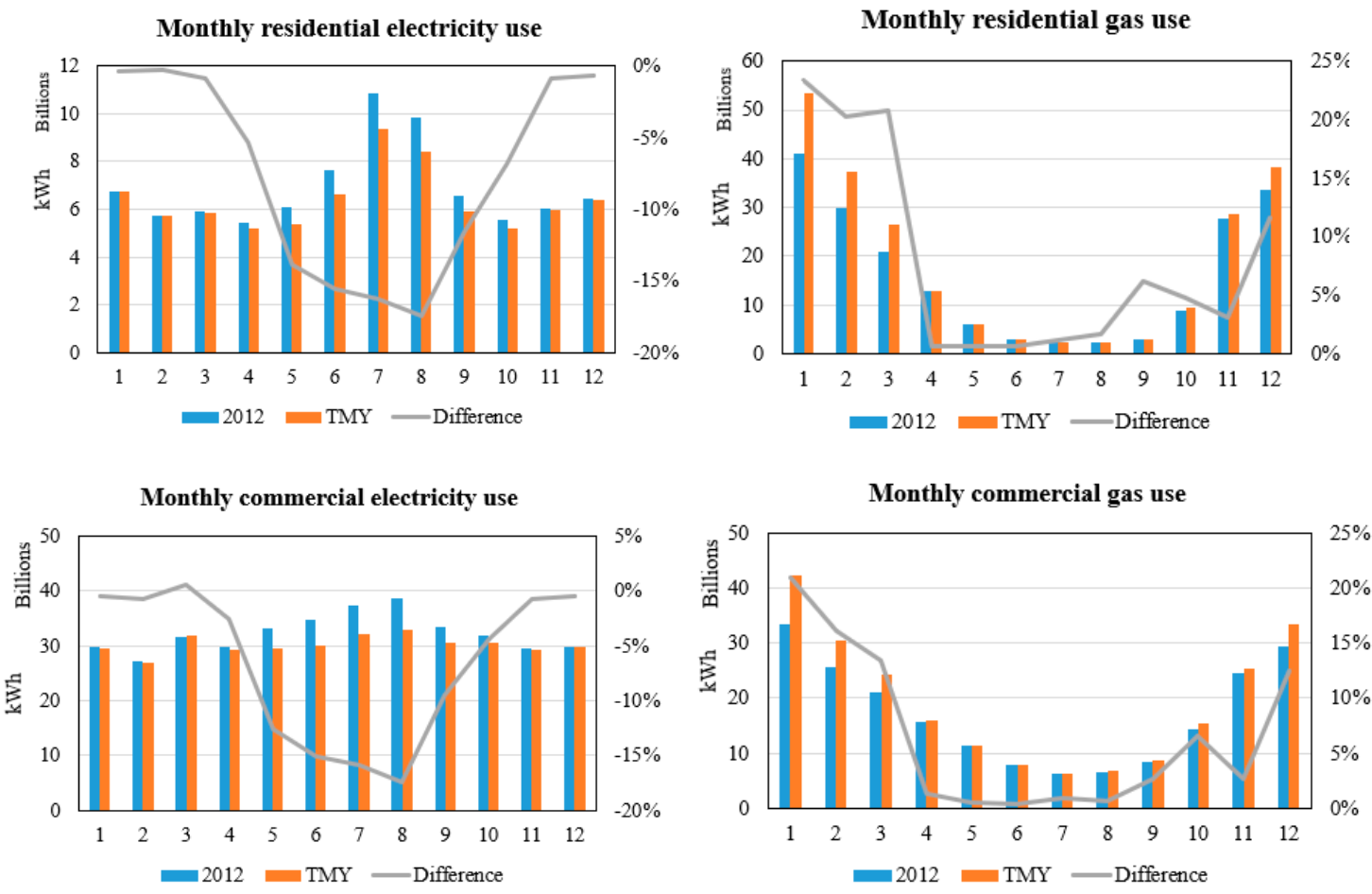

Figure 12. Comparative analysis of the modeled energy use by using localized weather data and TMY weather data.

\section{Conclusions}

In this study, the building energy-use dynamics of Manhattan, NYC, was modeled through integrating localized weather data and UBEM. Specifically, this study generated localized weather data based on the collected urban physical parameters and observed hourly weather data using UWG. A building energy-use model was established and calibrated for Manhattan, NYC, based on the collected RECS and CBEC reference data. Finally, building energy use was simulated and explored, to observe the spatial and temporal patterns of Manhattan, NYC.

The analysis results suggest several major conclusions. Firstly, the largest building electricity and gas uses are located in the center of Manhattan, which is mainly covered by commercial buildings with the largest building density and height. Secondly, similar seasonal electricity-use patterns and different seasonal gas-use patterns could be found in Manhattan. Specifically, the building electricity use is stable throughout all seasons. The largest gas consumption could be found in the winter due to high heating demand and low gas consumption in the summer as the gas is only used for water heating and cooking purpose. Thirdly, the summer energy use hourly profiles show only one peak for electricity use, mainly contributed by the high cooling demand. Winter energy use hourly profiles suggest two gas-use peaks. The first one is in the morning as people started working with high heating demand, and the second peak is associated with high heating demand from residential buildings when people finish their daily work and get back home.

While building energy use has been improved with localized weather data, there are still some other issues that need to be considered in the future, such as including the economic activity in the energy-use model. This study only modeled building energy use in the past. However, the understanding of future building energy use may be even more important as it could provide reference support for sustainable city planning. In 2014, the Intergovernmental Panel on Climate Change (IPCC) has released the fifth assessment report about future climate change, and the simulated future weather under different socio-development scenarios have been widely used in many studies already [52-54]. Therefore, one possible future research direction could be estimating future building energy use with consideration of both the local microclimate and future climate change under different scenarios. 
In addition, the same building occupancy schedule was applied in the same building group in this study. However, buildings located in a different part of the city may have different occupancy schedules. Therefore, another future research direction could be improving building energy-use modeling with actual building occupancy schedules extracted from other data sources, such as socio-media data (e.g., Twitter. Facebook, etc.). Moreover, more accurate reference data is needed to improve the model performance. In this study, only the RECS and CBECS data from EIA in 2009 and 2012 were used as the reference data for model calibration. While the calibration performance is acceptable, the collected RECS and CBECS data are not very recent data; thus, the calibrated model may not be able to consider the current energy use conditions as impacted by the economy. The EIA is going to release new data in the future. The model could be updated later with new recent data to improve the performance. Moreover, the RECS and CBECS data are reported only at the regional level and the calibrated model may have a much better reflection of energy use at the regional level instead of the individual building level. In addition, the spatial information of the reference data from RECS and CBECS has been blocked to for privacy purposes. Only one energy-use model can be calibrated for one building type, and the spatial variation in energy use of each building type was ignored. When smart-metered utility data become available, the proposed model can be updated and improved for better modeling of building energy use at the individual building level, with consideration of the spatial variation in energy use within each building type.

Funding: This research was supported by the Faculty First Award and Sustainability Faculty Fellowship from the University of North Carolina at Greensboro.

Acknowledgments: I would like to thank three reviewers for their constructive suggestions on an earlier version of this manuscript.

Conflicts of Interest: The author declares no conflict of interest.

\section{References}

1. Li, W.; Wu, C.; Zang, S. Modeling urban land use conversion of Daqing City, China: A comparative analysis of "top-down" and "bottom-up" approaches. Stoch. Environ. Res. Risk Assess. 2012, 28, 817-828. [CrossRef]

2. United Nations, Department of Economic and Social Affairs, Population Division. World Urbanization Prospects: The 2018 Revision (ST/ESA/SER.A/420); United Nations: New York, NY, USA, 2019.

3. Ma, R.; Geng, C.; Yu, Z.; Chen, J.; Luo, X. Modeling city-scale building energy dynamics through inter-connected distributed adjacency blocks. Energy Build. 2019, 202, 109391. [CrossRef]

4. Davila, C.C.; Reinhart, C.F.; Bemis, J.L. Modeling Boston: A workflow for the efficient generation and maintenance of urban building energy models from existing geospatial datasets. Energy 2016, 117, 237-250. [CrossRef]

5. Boston, G. Climate Action Plan Update; The City of Boston: Boston, MA, USA, 2014.

6. City of New York. One City Built to Last-Transforming New York City Buildings for a Low-Carbon Future; City of New York: New York, NY, USA, 2014.

7. Ei, D.; Usdoe, E.I.A. Annual Energy Outlook 2009 with Projections to 2030; Government Printing Office: Washington, DC, USA, 2009.

8. Parshall, L.; Gurney, K.; Hammer, S.A.; Mendoza, D.; Zhou, Y.; Geethakumar, S. Modeling energy consumption and $\mathrm{CO} 2$ emissions at the urban scale: Methodological challenges and insights from the United States. Energy Policy 2010, 38, 4765-4782. [CrossRef]

9. IEEJ. IEEJ Outlook 2018; The Institute of Energy Economics: Tokyo, Japan, 2018; pp. 1-116. Available online: https://www.ief.org/_resources/files/events/ief-lecture---ieej-energy-outlook-2018--prospects/ieej -outlook-2018-executive-summary.pdf (accessed on 10 August 2019).

10. Zhou, Y.; Clarke, L.; Eom, J.; Kyle, P.; Patel, P.; Kim, S.H.; Dirks, J.; Jensen, E.; Liu, Y.; Rice, J.; et al. Modeling the effect of climate change on U.S. state-level buildings energy demands in an integrated assessment framework. Appl. Energy 2014, 113, 1077-1088. [CrossRef]

11. Li, W.; Zhou, Y.; Cetin, K.; Eom, J.; Wang, Y.; Chen, G.; Zhang, X. Modeling urban building energy use: A review of modeling approaches and procedures. Energy 2017, 141, 2445-2457. [CrossRef] 
12. Li, W.; Zhou, Y.; Cetin, K.S.; Yu, S.; Wang, Y.; Liang, B. Developing a landscape of urban building energy use with improved spatiotemporal representations in a cool-humid climate. Build. Environ. 2018, 136, $107-117$. [CrossRef]

13. Zhou, Y.; Eom, J.; Clarke, L. The effect of global climate change, population distribution, and climate mitigation on building energy use in the U.S. and China. Clim. Chang. 2013, 119, 979-992. [CrossRef]

14. Yu, S.; Eom, J.; Zhou, Y.; Evans, M.; Clarke, L. Scenarios of building energy demand for China with a detailed regional representation. Energy 2014, 67, 284-297. [CrossRef]

15. Chen, Y.; Hong, T.; Piette, M.A. Automatic generation and simulation of urban building energy models based on city datasets for city-scale building retrofit analysis. Appl. Energy 2017, 205, 323-335. [CrossRef]

16. Reinhart, C.F.; Cerezo Davila, C. Urban building energy modeling-A review of a nascent field. Build. Environ. 2016, 97, 196-202. [CrossRef]

17. Ching, F.D.; Winkel, S.R. Building Codes Illustrated: A Guide to Understanding the 2018 International Building Code; John Wiley \& Sons: Hoboken, NJ, USA, 2018.

18. Swan, L.G.; Ugursal, V.I. Modeling of end-use energy consumption in the residential sector: A review of modeling techniques. Renew. Sustain. Energy Rev. 2009, 13, 1819-1835. [CrossRef]

19. Howard, B.; Parshall, L.; Thompson, J.; Hammer, S.; Dickinson, J.; Modi, V. Spatial distribution of urban building energy consumption by end use. Energy Build. 2012, 45, 141-151. [CrossRef]

20. Kavgic, M.; Mavrogianni, A.; Mumovic, D.; Summerfield, A.; Stevanovic, Z.; Djurovic-Petrovic, M. A review of bottom-up building stock models for energy consumption in the residential sector. Build. Environ. 2010, 45, 1683-1697. [CrossRef]

21. Hirst, E.; Lin, W.; Cope, J. A residential energy use model senstive to demographic, economic, and technological factors. Q. Rev. Econ. Financ. 1977, 17, 7-22.

22. Zhang, Q. Residential energy consumption in China and its comparison with Japan, Canada, and USA. Energy Build. 2004, 36, 1217-1225. [CrossRef]

23. Öztürk, H.K.; Canyurt, O.E.; Hepbasli, A.; Utlu, Z. Residential-commercial energy input estimation based on genetic algorithm (GA) approaches: An application of Turkey. Energy Build. 2004, 36, 175-183. [CrossRef]

24. Canyurt, O.E.; Öztürk, H.K.; Hepbasli, A.; Utlu, Z. Estimating the Turkish residential-commercial energy output based on genetic algorithm (GA) approaches. Energy Policy 2005, 33, 1011-1019. [CrossRef]

25. Li, X.; Zhou, Y.; Sha, Y.; Jia, G.; Li, H.; Li, W. Urban heat island impacts on building energy consumption: A review of approaches and findings. Energy 2019, 174, 407-419. [CrossRef]

26. Hirst, E.; Goeltz, R.; White, D. Determination of household energy using 'finger-prints' from energy billing data. Energy Res. 1986, 10, 393-405. [CrossRef]

27. Fung, A.S.; Aydinalp, M.; Ugursal, V.I. Econometric Models for Major Residential Energy End-Uses; CREEDAC-1999-04-05 Report; Dalhousie University: Halifax, NS, Canada, 1999.

28. Parti, M.; Parti, C. The total and appliance-specific conditional demand for electricity in the household sector. Bell J. Econ. 1980, 11, 309. [CrossRef]

29. Aydinalp, M.; Ugursal, V.I.; Fung, A.S. Modeling of the appliance, lighting, and space-cooling energy consumptions in the residential sector using neural networks. Appl. Energy 2002, 71, 87-110. [CrossRef]

30. Aydinalp, M.; Ugursal, V.I.; Fung, A.S. Effects of socioeconomic factors on household appliance, lighting, and space cooling electricity consumption. Int. J. Glob. Energy Issues 2003, 20, 302. [CrossRef]

31. Robinson, D.; Haldi, F.; Kämpf, J.H.; Leroux, P.; Perez, D.; Rasheed, A.; Wilke, U. CitySim: Comprehensive micro-simulation of resource flows for sustainable urban planning. In Proceedings of the Eleventh International IBPSA Conference, Glasgow, UK, 27-30 July 2009.

32. Reinhart, C.; Dogan, T.; Jakubiec, J.A.; Rakha, T.; Sang, A. Umi-an urban simulation environment for building energy use, daylighting and walkability. In Proceedings of the 13th Conference of International Building Performance Simulation Association, Chambery, France, 25-28 August 2013; Available online: https://www.aivc.org/sites/default/files/p_1404.pdf (accessed on 10 August 2019).

33. Reinhart, C.; Nagpal, S.; Davila, C.C. Chicago Energy Bazar. 2017. Available online: http://web.mit.edu/sust ainabledesignlab/projects/UBEM_Chicago/index.html (accessed on 10 August 2019).

34. Reinhart, C.; Monteiro, C.S.; Davila, C.C.; Arsano, A.; Turan, I.; Benis, K. UBEM Lisbon-A New Look at Old Buildings; Workshop Held in Lisbon on March 21 2018. Available online: http://web.mit.edu/sustainabledes ignlab/projects/UBEM_Lisbon/Lisbon_ANewLookAtOldBuildings.pdf (accessed on 10 August 2019). 
35. De Wolf, C.; Cerezo, C.; Murtadhawi, Z.; Hajiah, A.; Al Mumin, A.; Ochsendorf, J.; Reinhart, C. Life cycle building impact of a Middle Eastern residential neighborhood. Energy 2017, 134, 336-348. [CrossRef]

36. Sokol, J.; Davila, C.C.; Reinhart, C.F. Validation of a Bayesian-based method for defining residential archetypes in urban building energy models. Energy Build. 2017, 134, 11-24. [CrossRef]

37. Rose, C.M.; Saratsis, E.; Aldawood, S.; Dogan, T.; Reinhart, C.F. A Tangible Interface for Collaborative Urban Design for Energy Efficiency, Daylighting, and Walkability. In Proceedings of the 14th Conference of International Building Performance Simulation Association, Hyderabad, India, 7-9 December 2015.

38. Scofield, J.H. Efficacy of LEED-certification in reducing energy consumption and greenhouse gas emission for large New York City office buildings. Energy Build. 2013, 67, 517-524. [CrossRef]

39. Ma, J.; Cheng, J.C. Estimation of the building energy use intensity in the urban scale by integrating GIS and big data technology. Appl. Energy 2016, 183, 182-192. [CrossRef]

40. Olivo, Y.; Hamidi, A.; Ramamurthy, P. Spatiotemporal variability in building energy use in New York City. Energy 2017, 141, 1393-1401. [CrossRef]

41. Chan, A. Developing a modified typical meteorological year weather file for Hong Kong taking into account the urban heat island effect. Build. Environ. 2011, 46, 2434-2441. [CrossRef]

42. Bueno, B.; Norford, L.; Hidalgo, J.; Pigeon, G. The urban weather generator. J. Build. Perform. Simul. 2013, 6, 269-281. [CrossRef]

43. White Box Technologies. Weather Data for Energy Calculations. 2019. Available online: http://weather.whit eboxtechnologies.com/ (accessed on 1 August 2019).

44. US EIA. Residential Energy Consumption Survey (RECS). 2015. Available online: https://www.eia.gov/cons umption/residential/ (accessed on 11 September 2018).

45. US EIA. Commercial Building Energy Consumption Survey (CBECS). 2012. Available online: https: //www.eia.gov/consumption/commercial/ (accessed on 11 September 2018).

46. DOE. Residential Prototype Building Models. 2019. Available online: https://www.energycodes.gov/develo pment/residential/iecc_models (accessed on 10 August 2019).

47. DOE. Commercial Reference Buildings. 2019. Available online: https://www.energy.gov/eere/buildings/co mmercial-reference-buildings (accessed on 1 August 2019).

48. National Renewable Energy Laboratory. U.S. Department of Energy Commericial Reference Building Models of the National Building Stock. Teachnic Report. Available online: https://www.nrel.gov/docs/fy11osti/46861 .pdf (accessed on 10 August 2019).

49. The Engineering Toolbox. Available online: https://www.engineeringtoolbox.com/indoor-design-temperatu res-d_109.html (accessed on 10 August 2019).

50. School Calendar from the Department of Education in the City of New York. Available online: https: //www.schools.nyc.gov/calendar?school_years=1\%7C2019-2020\&mpp=12 (accessed on 10 August 2019).

51. Building Enery Models from PNNL. Available online: https://www.energycodes.gov/development/commer cial/prototype_models (accessed on 10 August 2019).

52. IPCC. Climate Change 2014: Synthesis Report. Contribution of Working Groups I, II and III to the Fifth Assessment Report of the Intergovernmental Panel on Climate Change; Meyer, C.W., Ed.; IPCC: Geneva, Switzerland, 2014.

53. Solecki, W.; Rosenzweig, C.; Dhakal, S.; Roberts, D.; Barau, A.S.; Schultz, S.; Ürge-Vorsatz, D. City transformations in a $1.5^{\circ} \mathrm{C}$ warmer world. Nat. Clim. Chang. 2018, 8, 177-181. [CrossRef]

54. Flörke, M.; Schneider, C.; McDonald, R.I. Water competition between cities and agriculture driven by climate change and urban growth. Nat. Sustain. 2018, 1, 51-58. [CrossRef]

(C) 2020 by the author. Licensee MDPI, Basel, Switzerland. This article is an open access article distributed under the terms and conditions of the Creative Commons Attribution (CC BY) license (http://creativecommons.org/licenses/by/4.0/). 